\title{
The Prevalence and Frequency of Authorial Identity among Undergraduate Students in Fiji
}

\author{
Jasbir Karneil Singh ${ }^{1 *}$, Ben K. Daniel ${ }^{2}$ \\ ${ }^{1}$ School of Communication, Language \& Literature, Fiji National University, P. O. Box 7222, Nasinu, Fiji \\ ${ }^{2}$ Higher Education Development Centre, University of Otago, P. O. Box 56, Dunedin 9054, New Zealand
}

Corresponding Author: Jasbir Karneil Singh, E-mail: jasksing@gmail.com

\begin{tabular}{l} 
ARTICLE INFO \\
\hline Article history \\
Received: May 16, 2018 \\
Accepted: August 07,2018 \\
Published: November 01, 2018 \\
Volume: 7 Issue: 6 \\
Advance access: September 2018 \\
\hline Conflicts of interest: None \\
Funding: The research was conduct- \\
ed as part of the author's completion \\
of a Masters in Higher Education that \\
was sponsored by the New Zealand \\
Ministry of Foreign Affairs \& Trade.
\end{tabular}

\begin{abstract}
Expressing an authoritative voice is an essential part of academic writing at university. However, the performance of the authorial self in writing is complex yet fundamental to academic success as a large part of academic assessment involves writing to the academy. More specifically, the performance of the authorial self can be complex for English as a Second Language (ESL) student-writers. This research investigated the extent to which ESL first-year students at the Fiji National University perform their authorial voice using interactional metadiscourse in their academic writing. The study employed a quantitative analysis of corpus produced by 16 Fijian ESL undergraduate students enrolled in an EAP course. The research found that the ESL authorial voice was predominantly expressed through boosters and attitude markers, with relatively little usage of other interactional metadiscoursal elements such as hedges, engagement markers and self-mentions. Further, the research showed that this particular cohort expressed their authorial voice and identity through boosted arguments and avoiding language that directly mentions the authorial self. The study concludes that the ESL authorial self for this cohort manifests itself in a selected range of selected interactional metadiscoursal elements, requiring the need to raise the awareness of self-reflective expressions for ESL students. The study also encourages further exploration of ESL authorial identity construction in academic writing at undergraduate level and beyond.
\end{abstract}

Key words: ESL, Metadiscourse, Interactional Metadiscourse, Academic Writing, Authorial Self, Authorial Identity

\section{INTRODUCTION}

\section{Background}

Academic writing is key to success for students at university. Writing skills are part of the core study skills students need to succeed. In other words, the performance of academic writing can determine the extent to which students are considered successful in higher education. Educational institutions use academic writing as a core mechanism for assessing students' learning and development, and their understanding of the knowledge they have gained. However, academic writing can be complex in that there is a large amount of tacit knowledge involved in the production of academic texts (Elton, 2010). Further, success in academic writing requires students to adapt to the specific types of discourse as determined by various domains. As Swales (1990) noted, universities have agreed upon styles and techniques of written communication within academic disciplines - a phenomenon known as discourse communities. However, a lack of familiarity with the explicit or implicit rules of academic writing can lead to an absence of assuredness amongst university students. Further, eagerness to become part of the academic community, and the fear of sounding 'wrong' can make students devalue the expression of their voice. The problem can be more pronounced for English as a Second Language (ESL) writers, who face more nuanced issues of self-efficacy in English writing (Lin, 2015; Nelson, 1991), and as such may undervalue the expression of their personal voice and opinions, which could make it difficult to develop a confident authorial voice in written work.

Developing a strong and confident authorial voice is an integral part of teaching and learning. Developing the authorial voice leads to a more confident and expressive authorial identity in writing. Increasing our understanding of students' perceptions of their authorial voice and identity can help policy-makers and educators design teaching and learning practices that empower and enable the budding student-writer. Research has shown that putting the expression of students' ideas and opinions at the forefront of essay writing can empower student-writers (Lillis, 1997). Also, teaching practices that acknowledge students' personal voices in writing are beneficial for both students and teachers. They encourage students to develop confidence and feel that teachers care more about what they say, which in turn motivate them to 
put more effort in what they write and how they present it (Gemmell, 2008).

However, the question then arises - how can voice in writing, and thus the development of authorial identity, be investigated? In an attempt to answer this question, the present research began by conceptualising authorial voice as a reflection of the authorial identity. An authorial voice is indicated through writing choices and techniques referred to collectively as rhetorical strategies. The fundamental idea is that voice and identity in student writing are expressed through the particular linguistic decisions the student-writer makes regarding the choice of words and styles that convey their personal stance and engagement with readers, as well the choices about the degree to which they express such stance and engagement. The research was designed to explore the extent to which Fiji ESL undergraduate students express their authorial voice in their writing, which was primarily investigated through an examination of students' written essays.

\section{Significance of the Issue}

A pertinent issue regarding ESL student-writers constructing and expressing their identity in their writing is finding the extent to which they are aware of and utilise the language they can use to reveal their personal identity - their voice - in writing. This issue is more noteworthy given that the explicit teaching of rhetorical strategies can help ESL writers improve their authorial voice in academic writing (Jarkas \& Fakhreddine, 2017). One of the main aspects of student academic writing is student-writers developing the ability to negotiate their voice into their text using appropriate rhetorical strategies; it stands to reason, then, that the teaching and learning of ESL academic writing needs to ensure that ESL student-writers develop a mindfulness of the appropriate rhetorical strategies they can use to make their voice more visible in their texts.

Notably, there is no research exploring how Pacific Island ESL students express their personal voice in their academic writing. While there has been an exploration of how students express their voice using metadiscourse in countries such as South Africa (Ramoroka, 2017), Iran (Abdi, 2002, 2009; Rahimivand \& Kuhi, 2014; Salek, 2014), Yemen (Alward, Mooi, \& Bidin, 2012) and related research in the UK (Lillis, 1997), there appears to be no such research done for Pacific students. This is a significant gap as the Pacific tertiary education institutions cater to a large population of students who are ESL writers; non-native speakers of English face problems with their writing development (Swales, 1990) and these problems can be unique (Nelson, 1991). Moreover, English language learners face a variety of writing difficulties, among which the most common are cognitive/linguistic difficulties (Lin, 2015) - the use of rhetorical strategies fall within this category. In shedding light on the ESL student-writers' perceptions of their authorial identity, the findings further clarify rhetorical strategies of self-expression in an ESL context.

Success in the English language in Fiji carries high stakes. A pass in the English subject is required to pursue most high- er education studies at university - the method of assessment is a written exam, and this form of a high stakes written exam continues in many university courses, with a large part of the grade for a course determined by the English writing skills of a learner. Moreover, the majority of assessments in Fiji universities consist of some form of English composition. These expectations emphasise the English writing skills, as well as the teaching and learning of rhetorical strategies in the context of English academic writing in the Fiji education system. However, a recent study has found that Fiji students may not be prepared to demonstrate desirable writing competence at university due to inadequate second language teaching training and teacher development (Nicholls, 2014). Other academics describe English language skills problems in Fiji as "pervasive", with the cause being a general failure to recognise the implications associated with learning and teaching English as a second language (Maharaj, 2014). Moreover, while the role of personal voice in academic writing is critical in advancing authorial identity and ultimately improving competence in academic writing, little research is available to inform how students can be empowered regarding expressing their personal stance and voice, and by extension, their authorial identity in academic writing. This is a concern as issues of self-efficacy and the expression of an authoritative authorial voice in academic writing can be particularly troublesome for ESL students. Therefore, it becomes imperative to explore issues of academic English writing that ESL university students may be facing.

An exploration of how Fiji ESL student-writers represent themselves in academic writing is beneficial for teachers and students as well. ESL teachers can benefit from an increased understanding of how - and the level to which - students are expressing their voice in academic writing. This would lead to increased insight into students' understandings of propositional content and thus lead to better feedback. This increased awareness of the ESL student-writer's voice in writing can inform writing instruction and lead to students' benefitting from an increased emphasis on the expression of their voice and identity in academic writing - increased authorial voice in academic writing, which then represents an increase in authorial identity, can be seen as a form of empowerment, alongside having the added benefit of making the ESL student's argument clearer and more persuasive (Jarkas \& Fakhreddine, 2017). Fundamentally, this study contributes towards a growing discussion of writing as social engagement. This study, then, investigates the extent to which first-year Fiji students at the Fiji National University use particular functions of metadiscourse to express their authorial voice in their academic writing, and what it reveals about their perceptions of themselves and their audience.

\section{Authorial Identity and Voice}

Research describes authorial identity as "the sense a writer has of themselves as an author and the textual identity they construct in their writing" (Pittam, Elander, Lusher, Fox, \& Payne, 2009, p. 153). This description is grounded in literary critic and philosopher Michel Foucault's ideas of the relationship between the writer and the text, particularly in 
the way the text can point towards the voice and identity of the writer. This research draws from these assumptions that there is a fundamental connection between the author and the text and that in the act of academic writing, the student as a writer (the student-writer) inputs reflections of their authorial identity in their academic writing. This authorial identity is expressed in writing and becomes noticeable when the writer sees themselves as an author, and expresses that identity through the authorial voice.

Notably, though, academic writing often requires the writer to remove explicit expressions of their own personal stance; students and other academic writers usually follow the norms of academic writing deemed appropriate by their academic discipline, such as grounding the writing in explicit objectivity. Student-writers conform to these rules of academic writing to seek membership within what Swales (1990) calls a discourse community - an academic community which practices agreed upon conventions of discourse and so in following the conventions of academic writing within their disciplines, students gain acceptance into the discipline's community (Rahimivand \& Kuhi, 2014). This practice also assumes that the student develops an authorial identity that conforms to their disciplines' discourse by manipulating the strength/explicitness of their personal voice in their academic writing. Thus, an exploration of how students project their voice in writing can be seen as an investigation of how they contribute to the discoursal collective identity through writing and subscribe to the protocols of discourse and communications in the community.

The reasoning behind treating linguistic choices in writing as expressions of voice is grounded in this research's use of linguist Ken Hyland's theories of disciplinary discourse, which explore the way in which the writing conventions of academic disciplines affect writing styles (Hyland, 2004). While most of Hyland's work examines how disciplinary conventions affect academic writing practices, his ideas on authorial identity in academic writing (Hyland, 2002a) and how students as writers interact with the social construction of knowledge in academic discourse (Hyland, 2008) significantly motivated the work presented in this research. In particular, this study makes use of Hyland's conceptualisation of a specific set of linguistic functions - called metadiscourse (Hyland \& Tse, 2004) - that a writer can use to indicate confidence, stance and personal beliefs. Metadiscourse is used as an essential analytical tool for exploring voice in academic writing. Metadiscourse usage is classified as a rhetorical strategy, where rhetorical strategies are the choices a student-writer makes regarding the particular choice of words and linguistic styles in expressing their stance, engagement and confidence. Also, the study considers metadiscourse usage as an extension and presentation of authorial identity in academic writing.

This conceptualisation of voice as the employment of particular rhetorical strategies by the student-writer is supported by other interpretations of voice in academic texts that describe voice as encapsulating the writer's relationship to the words (Elbow, 1988) as well as linking ideas and ar- ranging parts of discourse together (Hickey, 1993). Moreover, a voice in writing is implied in what linguists (Cheng \& Steffensen, 1996; Halliday, 1978, 1985) consider the interpersonal function of language - the role of language which is separate from the propositional content of the text and deals instead with linguistic features that the writer uses to establish interpersonal relations. Basically, voice in writing shows how the writer interacts with their audience, as well as expresses their feelings about the content of the text.

The writer's voice is generally considered "the use of language that articulates the author's position clearly, particularly about other voices or texts" (Jarkas \& Fakhreddine, 2017 , p. 242). However, the development of the authorial voice in writing remains a complicated issue, partly due to the "elusive nature" of voice (Zhao, 2012, p. 201), which has led to a lack of clarity when it comes to the concept of authorial voice (Jarkas \& Fakhreddine, 2017). The consequence of this issue is that students who want to replicate the perceived standards of academia could end up producing texts which are merely regurgitating the opinions of more established authors.

\section{THEORETICAL FRAMEWORK}

This study explores ESL student-writer identity through their writings. It treats writing as an act of identity negotiation for the student-writer, based on Ivanič's (1998) model of identity. According to this model, identity is plural and continually changing notion with four inter-related strands of selfhood:

- autobiographical self - what the writer brings to the act of writing, such as their past experiences, including their roots and literacy practices;

- discoursal self - the persona the writer adopts when writing, that is, the voice they want the readers to hear. This voice is the writer's conscious and unconscious self-representation in the text, and is constructed through the discourse characteristics of a text; this also, then, reflects the values, beliefs and power relations of the social context in which the text is produced;

- authorial self - the authoritativeness of the writer; their position, opinions, and beliefs which influence how willing the writer is to make claims and their reliance on other voices to support their claims, by extension, how they strive to achieve recognition from readers;

- the possibilities for selfhood development - an abstract notion about the various socially available possibilities for selfhood in the writer's socio-cultural or institutional context, and how these possibilities influence writing choices; the idea is that the writer constructs the discoursal self by choosing a possibility that is supported by the context.

From the assumptions described in the framework above, the writer is continually negotiating between the strands of selfhood mentioned above. The fundamental premise of this study, then, is that the ESL student-writer negotiates between the individual rhetorical self and the societal influence on their self-expression in writing (Prior, 2001; Riyanti, 2015; Sperling, Appleman, Gilyard, \& Freedman, 2011). This balancing act happens because the 
ESL student-writers are part of a discourse community which constructs shared meaning. The ESL writer in this regard attempts to become part of the discourse community. According to Ivanič's (1998) theoretical model, the writer's self is continuously negotiated as an identity is constructed. Therefore, the way the writer expresses their relationship to the community, their authorial voice and identity are mostly dependent on their ability to develop self-expressive awareness, supported by the use of the rhetorical strategies and identity development.

\section{Metadiscourse}

An exploration of students' authorial identity and voice in the text is concerned with how students balance their voice with academic writing conventions, and this is where Hyland's concept of metadiscourse (Hyland \& Tse, 2004) was central for this study. While there are other theories of how authorial identity is constructed, and varying versions of the concept of metadiscourse, Hyland's concept of metadiscourse (2002b; Hyland \& Tse, 2004) was fundamental for this study as it explicitly categorizes a range of functions (see Table 1) which can be used to explore how a student-writer expresses their identity.

Metadiscourse functions are a range of words which have specific functions that help the student-writer insert their own feelings, opinions (of varying strength) and interact with the reader. However, the concept of metadiscourse is complex because metadiscourse is not an explicit set of words but rather a consideration of the exact function of the words in the text - if a word or phrase serves one or more metadiscoursal purposes (see Table 1), then it can be considered a metadiscourse marker. Metadiscourse devices reflect common academic/social practice and "helps writers to show their awareness of social negotiation of knowledge and their efforts to pursue their claims and gains in the...disciplines" (Rahimivand \& Kuhi, 2014, p. 1494). Interactional metadiscourse markers, in particular, are closely associated with the writers' personal stance, voice and identity (Thompson, 2001).

When a student essay is analysed to reveal how the student-writer uses metadiscourse to insert their own voice in their writing, then the voice of the student-writer in the text can be measured - the presence and strength of the authorial voice in the text then indicates the authorial identity of the writer. Metadiscourse and its functions are divided into categories of interactive and interactional resources - the underlying principle is still that metadiscourse are rhetorical strategies, and one of its functions is to represent the writer in writing.

Interactive metadiscourse (Thompson \& Thetela, 1995 ) are words used to guide the reader through the text, and show the writer's anticipation of the readers' reaction and needs. Interactional metadiscourse attempts to bring in the writer's voice, and it is connected to writer's identity as it is motivated by the writer's culture (Thompson, 2001). As such, interactional metadiscourse features represent a personal voice in writing (Ramoroka, 2017), and are essentially self-reflective expressions
Table 1. A model of metadiscourse in academic texts (Hyland \& Tse, 2004)

\begin{tabular}{|c|c|c|}
\hline Category & Function & Examples \\
\hline Interactive resources & \multicolumn{2}{|c|}{ Help to guide reader through the text } \\
\hline Transitions & $\begin{array}{l}\text { express semantic } \\
\text { relation between main } \\
\text { clauses }\end{array}$ & $\begin{array}{l}\text { in addition/but/thus/ } \\
\text { and }\end{array}$ \\
\hline Frame markers & $\begin{array}{l}\text { refer to discourse acts, } \\
\text { sequences, or text } \\
\text { stages }\end{array}$ & $\begin{array}{l}\text { finally/to conclude/my } \\
\text { purpose here is to }\end{array}$ \\
\hline Endophoric markers & $\begin{array}{l}\text { refer to information in } \\
\text { other parts of the text }\end{array}$ & $\begin{array}{l}\text { noted above/sec Fig/in } \\
\text { section } 2\end{array}$ \\
\hline Evidentials & $\begin{array}{l}\text { refer to source of } \\
\text { information from other } \\
\text { texts }\end{array}$ & $\begin{array}{l}\text { according to } X /(Y \text {, } \\
1990) / Z \text { states }\end{array}$ \\
\hline Code glosses & $\begin{array}{l}\text { help readers grasp } \\
\text { functions of ideational } \\
\text { material }\end{array}$ & $\begin{array}{l}\text { namely/e.g./such as/in } \\
\text { other words }\end{array}$ \\
\hline Interactional resources & \multicolumn{2}{|c|}{ Involve the reader in the argument } \\
\hline Hedges & $\begin{array}{l}\text { withhold writer's full } \\
\text { commitment to } \\
\text { proposition }\end{array}$ & $\begin{array}{l}\text { might/perhaps/possible/ } \\
\text { about }\end{array}$ \\
\hline Boosters & $\begin{array}{l}\text { emphasize force or } \\
\text { writer's certainty in } \\
\text { proposition }\end{array}$ & $\begin{array}{l}\text { in fact/definitely/it is } \\
\text { clear that }\end{array}$ \\
\hline Attitude markers & $\begin{array}{l}\text { express writer's } \\
\text { attitude to proposition }\end{array}$ & $\begin{array}{l}\text { unfortunately/I agree/ } \\
\text { surprisingly }\end{array}$ \\
\hline Engagement markers & $\begin{array}{l}\text { explicitly refer to or } \\
\text { build relationship with } \\
\text { reader }\end{array}$ & $\begin{array}{l}\text { consider/note that/you } \\
\text { can see that }\end{array}$ \\
\hline Self-mentions & $\begin{array}{l}\text { explicit reference to } \\
\text { author(s) }\end{array}$ & I/we/my/our \\
\hline
\end{tabular}

of identity. Metadiscourse, with its capacity for expressing writer identity and facilitating interaction with the imagined audience of a text, can be considered as an essential rhetorical strategy for the teaching and learning of academic writing. Maintaining control over the use of metadiscourse is critical to the writer's personal voice and visibility in the text (Truesdell, 2014). Interactional categories from Hyland's (2004) model of metadiscourse - hedges, boosters, attitude markers, engagement markers, and self-mentions - were quantitatively analysed in the student-writers' texts. The frequency of these metadiscoursal markers was measured per 1000 words, in the same vein as previously published studies on the same topic (Harwood, 2005; Hyland, 2002b; Rahimivand \& Kuhi, 2014; Ramoroka, 2017). Ultimately, this study operates with the understanding that the relative frequency of metadiscourse interactional markers, in the fashion of other works on metadiscourse markers, correlates with authorial self-perception (Truesdell, 2014) and are indicators of the expression of an authorial voice.

The numerical results for the metadiscourse categories were used to conclude (Abdi, 2002; Ramoroka, 2017) about the student-writers' awareness and usage of metadiscourse strategies to create an authorial identity in academic writing. This was done using a theoretically justified cross-referencing (see Table 3) of particular themes from Leydens' (2008) continuum of rhetorical awareness with the frequency of interactional metadiscourse markers. 
Table 2. Initial rhetorical awareness continum (Leydens, 2008)

\begin{tabular}{|c|c|c|c|c|}
\hline \multicolumn{5}{|c|}{ INITIAL RHETORICAL AWARENESS CONTINUUM } \\
\hline Characteristics & Stage 1 & Stage 2 & Stage 3 & Stage 4 \\
\hline $\begin{array}{l}\text { Importance of } \\
\text { Rhetoric in } \\
\text { Professional } \\
\text { Communication }\end{array}$ & $\begin{array}{l}\text { Denial of the } \\
\text { relevance or } \\
\text { importance of rhetoric }\end{array}$ & $\begin{array}{l}\text { On the cusp between } \\
\text { denial and } \\
\text { acknowledgment }\end{array}$ & $\begin{array}{l}\text { Overt acknowledgment of } \\
\text { the importance of rhetoric }\end{array}$ & $\begin{array}{l}\text { Like stage } 3 \text { but with greater } \\
\text { emphasis on rhetoric's import }\end{array}$ \\
\hline Role of Writers & Data conveyers & $\begin{array}{l}\text { Data conveyers and } \\
\text { data guides }\end{array}$ & $\begin{array}{l}\text { Data providers and } \\
\text { spokespersons }\end{array}$ & $\begin{array}{l}\text { Data spokespersons and } \\
\text { providers }\end{array}$ \\
\hline Role of Readers & Data recipients & $\begin{array}{l}\text { Data recipients and } \\
\text { interpreters }\end{array}$ & Primarily data interpreters & Primarily data interpreters \\
\hline Writer Identity & $\begin{array}{l}\text { Writer identity is } \\
\text { irrelevant; data } \\
\text { persuades, so a } \\
\text { spokesperson is } \\
\text { unnecessary }\end{array}$ & $\begin{array}{l}\text { Writer identity is } \\
\text { minimized, seen as } \\
\text { novice, yet sometimes } \\
\text { writers need to } \\
\text { persuade readers }\end{array}$ & $\begin{array}{l}\text { Writer and engineer selves } \\
\text { are integrated; workplace } \\
\text { exigencies demand a keen } \\
\text { awareness of audience } \\
\text { and persuasion }\end{array}$ & $\begin{array}{l}\text { Writer and engineer selves } \\
\text { are more fully integrated; } \\
\text { confident change } \\
\text { agents/engineers know how } \\
\text { to marshal data to persuade } \\
\text { audiences }\end{array}$ \\
\hline $\begin{array}{l}\text { Career Stage/ } \\
\text { Organizational Role }\end{array}$ & $\begin{array}{l}\text { Early } \\
\text { undergraduates/ } \\
\text { perhaps some } \\
\text { internship experience }\end{array}$ & $\begin{array}{l}\text { Late undergraduates/ } \\
\text { internship and/or coop } \\
\text { experience }\end{array}$ & $\begin{array}{l}\text { Post-undergraduates/ full- } \\
\text { time career experience }\end{array}$ & $\begin{array}{l}\text { Post-undergraduates/ full- } \\
\text { time career and leadership } \\
\text { experience }\end{array}$ \\
\hline Role of Objectivity & $\begin{array}{l}\text { Objectivity is } \\
\text { paramount to good } \\
\text { science/ engineering }\end{array}$ & $\begin{array}{l}\text { Objectivity is important } \\
\text { for obtaining valid } \\
\text { results }\end{array}$ & $\begin{array}{l}\text { Objectivity is a worthy } \\
\text { ideal; also nonobjective } \\
\text { factors influence human } \\
\text { decisions }\end{array}$ & $\begin{array}{l}\text { Objectivity is a worthy ideal; } \\
\text { also nonobjective factors } \\
\text { influence human decisions }\end{array}$ \\
\hline
\end{tabular}

\section{Leydens' Continuum of Rhetorical Awareness}

With metadiscourse usage (above) as the basis for indicating authorial voice and identity, this research also utilised a continuum of rhetorical awareness as the instrument for measuring the expression of authorial identity. The continuum was a result of a phenomenological inquiry into student and faculty perspectives on the importance of rhetoric (Leydens, 2008). The continuum was used as a ruler for indicating what levels of metadiscourse usage indicate about the student-writers' performance of voice in writing (what Truesdell (2014) terms the outside perspective). The continuum describes various themes which have stages upon which a writer can be placed - this placement was determined by the analysis of their written text (essay - outside perspective).

This study utilises only four themes from Leydens' continuum of rhetorical awareness: "Importance of rhetoric" - the importance the writer places on the role of rhetoric in their writing; "Role of writer" - the writer's displayed perception of their role as a writer; "Role of reader" - the writer's displayed perception of the role of their readers; and "Writer Identity" - the writer's displayed perception of their authorial identity. These four themes are used in particular because they inter-relate on the core concept of this study: issues of authorial identity (Leydens, 2008). Moreover, the other themes in Leydens' continuum, such as the career stage, were not aspects that this study was considering.

\section{RESEARCH QUESTIONS OR OBJECTIVES}

1. To what extent do Fiji ESL first-year students at the Fiji National University use interactional metadiscourse as expressions of authorial voice and identity in their academic English writing?
2. What does the performance of authorial identity in writing reveal about the students' perceptions of their roles as writers and the role of their readers?

\section{METHODS AND PROCEDURES}

The research was conducted as a naturalistic constructivist case study (Riazi, 2016), where students' perception of reality was treated as multiple, subjective and context-specific. The sample was drawn from the population of ESL students from the Fiji National University campus. The study performed a corpus analysis of student text, where interactional metadiscourse markers were identified, with the goals of exploring the writer's construction of their identity. The research also modelled previous metadiscourse analysis (Ramoroka, 2017) in eliciting essays from undergraduate students to explore students' expressions of their personal voice in writing through a focus on the interactional metadiscourse features from Hyland's (2004) model of metadiscourse. This is because interactive metadiscourse involves the writer's anticipation of the readers' needs, while interactional metadiscourse involves the writer's voice. Thus, the primary data set for this research was the quantitative (frequency) analysis of the interactional metadiscourse markers.

\section{Sampling and Data Collection}

Through non-probability purposive sampling, sixteen students $(n=16)$ were chosen. Flyers were used to recruit participants for the study. The specific characteristics sought in volunteer participants included:

- the student had to be a first-year student at the Fiji National University;

- to draw stable conclusions about writing needs and discount the impact of extensive professional experience 
on writing ability, the age of the sample was restricted to $18-21$ years old;

- the students had to be Fiji nationals;

- $\quad$ the student had to be an ESL writer - a non-native speaker of English, with English as their second language.

The justification for the sampling approach is provided by accessibility and informant nomination being the decisive sampling factors used in other metadiscourse studies (Harwood, 2005; Hyland, 2002b; Rahimivand \& Kuhi, 2014).

For the data collection, each student was asked to write an academic essay on a topic from the essay assignment for the EAP course they were enrolled. These essays were then transcribed and prepared as word documents.

\section{Analytical Processes and Procedures}

A quantitative analysis of interactional metadiscourse markers in the essays was undertaken. The first step of this approach was to read the essays carefully, then code the words/phrases which were identified as performing an interactional metadiscourse function. The essays were reread carefully, and the frequency of chosen metadiscourse markers (see Table 1 - markers are the individual phrases/words which fall under a metadiscourse category) were identified manually (as in Rahimivand \& Kuhi (2014)). The transcripts were uploaded to NVivo, where interactional metadiscourse markers were coded from the text. The frequency of identified interactional metadiscourse markers was drawn from NVivo. As per the conventional practice in corpus analysis of smaller sizes (Lüdeling \& Kytö, 2009; McEnery \& Hardie, 2012), the frequency of a term per thousand words was performed (McEnery \& Hardie, 2012). In most examinations of textual features in the corpus, especially in cases such as presented here where all texts were not of the same length, the raw counts of features (such as metadiscourse markers) were not directly comparable across texts (Lüdeling \& Kytö, 2009). Thus, normalisation was used to convert the raw counts into rates of occurrence. Moreover, the normalisation was performed to word lengths which the corpus texts are close to (Lüdeling \& Kytö, 2009). In this study, since the sample typically writes essays within the $900-1000$ words range, the normalisation was done to a standard 1000 words. For instance, a raw count of 20 markers for a 700 -word long essay will lead to $20 / 700$ multiplied by 1000 , thus an occurrence rate of 28.57 per 1000 .

The average frequency per 1000 words was calculated for each category of interactional metadiscourse for the entire sample. This was then used to establish a high and low point of relative frequencies for the various interactional metadiscourse categories. According to the literature, each category of metadiscourse can be expressed in a variety of ways (Hyland \& Tse, 2004; Ramoroka, 2017; Truesdell, 2014). In other words, there is no strict list of exclusive words which are metadiscourse markers (Hyland \& Tse,
2004; Rahimivand \& Kuhi, 2014). Instead, the words have to be seen in the light of the function they perform (Hyland $\&$ Tse, 2004; Truesdell, 2014) in the context of the sentence. For example, the word "sometimes", even though not listed in Table 1, does serve to withhold the writer's full commitment to the proposition, and is thus treated as a hedge. Moreover, individual words/phrases can even perform more than one metadiscourse function (Hyland \& Tse, 2004; Ramoroka, 2017). For example, the phrase "to have a code...is right..." acts as both a booster (emphasises force) as well as an attitude marker (expressing the writer's attitude).

The relative usage of the interactional metadiscourse markers was used to place the students along particular aspects of Leydens' continuum of rhetorical awareness. This placement was done using the author's development of a theoretically-justified cross-referencing (Table 3) of relative frequencies of interactional metadiscourse with Leydens' continuum of rhetorical awareness.

How Table 3 works:

- the sample's placement on Leydens' continuum of rhetorical awareness (Table 2) was determined through the relative frequency of the five interactional metadiscourse categories (see Table 4 and 5) in their essay;

- example: the sample used a high number of boosters in their essays. (Note: whether a frequency is high or low is decided on their frequency relative to other metadiscourse markers. This is because metadiscourse statistics are meant to compare different patterns of occurrence of metadiscourse (Hyland, 2010));

- for the theme "Importance of rhetoric" from Leydens" continuum of rhetorical awareness, a high number of boosters showed that the students knew the importance of arguing claims persuasively and is a sign of an appreciation of rhetoric. In Table 3, this valuation was then cross-referenced with the particular themes from Leydens' continuum of rhetorical awareness;

- the result showed that the student sample was placed at Stage 3 for the theme "Importance of rhetoric" from the rhetorical awareness continuum. This was just the placement for boosters, though - for the average placements for this theme, the usage of all interactional metadiscourse markers had to be considered;

- thus, the same process was then followed for all other interactional metadiscourse markers for every theme from the rhetorical awareness continuum - accordingly, for the theme "Importance of rhetoric" in the rhetorical awareness continuum: high boosters $=$ Stage 3; relatively more common attitude markers $=$ Stage 1 ; low hedges $=$ Stage 1 ; low engagement markers $=$ Stage 1-2;

- the sample was then given an overall rating for the theme "Importance of rhetoric" based on an average of the various placements they received for their use of interactional metadiscourse.

Example, for the theme "Importance of rhetoric" (note: see 
Table 3. Usage of interactional metadiscourse cross-referenced with Leydens' continuum of rhetorical awareness

\begin{tabular}{|c|c|c|c|c|}
\hline & $\begin{array}{l}\text { Importance of } \\
\text { rhetoric (effective } \\
\text { persuasive writing) }\end{array}$ & Role of writers & Role of readers & $\begin{array}{l}\text { Writer identity (related: } \\
\text { expression of voice in writing) }\end{array}$ \\
\hline Hedges & $\begin{array}{l}\text { High number shows } \\
\text { writer is thoughtful } \\
\text { and pre-empts } \\
\text { outcomes to their } \\
\text { assumptions (Rahimivand } \\
\text { \& Kuhi, 2014) - implies } \\
\text { clear recognition of } \\
\text { rhetoric's importance } \\
\text { Note: have to be balanced } \\
\text { with boosters/attitude } \\
\text { markers for effective } \\
\text { rhetoric (Rahimivand \& } \\
\text { Kuhi, 2014) }\end{array}$ & $\begin{array}{l}\text { High usage } \\
\text { shows deferring } \\
\text { certainty (Truesdell, } \\
\text { 2014). This then } \\
\text { precludes the } \\
\text { writer from being } \\
\text { a spokesperson for } \\
\text { the content due to } \\
\text { lack of commitment } \\
\text { but can include } \\
\text { the possibility of } \\
\text { the writer as a data } \\
\text { guide. }\end{array}$ & $\begin{array}{l}\text { High number implies } \\
\text { giving authority to } \\
\text { readers (Rahimivand } \\
\text { \& Kuhi, 2014) - this } \\
\text { clearly means readers } \\
\text { as interpreters, not } \\
\text { mere recipients } \\
\text { Hedges which limit } \\
\text { commitment act as } \\
\text { a shield and hide } \\
\text { identity - lead to } \\
\text { passive voice. Implies } \\
\text { that readers are } \\
\text { interpreters of data } \\
\text { too (Truesdell, 2014) }\end{array}$ & $\begin{array}{l}\text { High usage means keeping } \\
\text { identity safe (Rahimivand \& } \\
\text { Kuhi, 2014), which means } \\
\text { minimal to zero visibility in text } \\
\text { Note: have to be balanced with } \\
\text { boosters/attitude markers for } \\
\text { effective rhetoric (Rahimivand \& } \\
\text { Kuhi, 2014) }\end{array}$ \\
\hline Boosters & $\begin{array}{l}\text { An important feature } \\
\text { in negotiating } \\
\text { claims and effective } \\
\text { argumentation in academic } \\
\text { writing (Rahimivand \& } \\
\text { Kuhi, 2014) - high usage } \\
\text { shows the writer knows } \\
\text { the importance of arguing } \\
\text { claims persuasively }\end{array}$ & $\begin{array}{l}\text { High usage } \\
\text { helps create an } \\
\text { authoritative persona } \\
\text { (Rahimivand \& } \\
\text { Kuhi, 2014). This } \\
\text { can lead to the writer } \\
\text { being much more } \\
\text { than a mere guide } \\
\text { of the data - they } \\
\text { can act as a } \\
\text { spokesperson for the } \\
\text { data due to the overt } \\
\text { commitment. }\end{array}$ & $\begin{array}{l}\text { Usage promotes } \\
\text { solidarity and } \\
\text { engagement with } \\
\text { readers (Rahimivand } \\
\text { \& Kuhi, 2014). } \\
\text { However, this does } \\
\text { not necessarily } \\
\text { mean readers are } \\
\text { seen as more than } \\
\text { recipients - the reader } \\
\text { could either be treated } \\
\text { as an interpreter and/ } \\
\text { or recipient }\end{array}$ & $\begin{array}{l}\text { Usage can reinforce construction } \\
\text { of identity through impact of } \\
\text { argument (Rahimivand \& Kuhi, } \\
2014 \text { ) - thus, high usage will } \\
\text { mean confidence in their ability } \\
\text { to create effects on the audience }\end{array}$ \\
\hline $\begin{array}{l}\text { Attitude } \\
\text { markers }\end{array}$ & $\begin{array}{l}\text { Low usage shows } \\
\text { acknowledgement of } \\
\text { dominance of reason over } \\
\text { emotion in academic } \\
\text { writing (Rahimivand \& } \\
\text { Kuhi, 2014). This can } \\
\text { indicate a preference } \\
\text { for following the rules } \\
\text { of academic writing as } \\
\text { the writer perceives it, } \\
\text { indicating at least implicit } \\
\text { importance placed on } \\
\text { rhetoric }\end{array}$ & $\begin{array}{l}\text { Low usage shows } \\
\text { the dominance of } \\
\text { reason (Rahimivand } \\
\& \text { Kuhi, } \\
\text { 2014) - implies } \\
\text { role as an impartial } \\
\text { data conveyer or, } \\
\text { depending on the } \\
\text { interactive language } \\
\text { used, a data guide. }\end{array}$ & $\begin{array}{l}\text { If the low usage of } \\
\text { attitude markers } \\
\text { shows the writer } \\
\text { attempting to sound } \\
\text { sophisticated, and } \\
\text { having a reluctance to } \\
\text { explicitly express their } \\
\text { stance (Rahimivand } \\
\& \text { Kuhi, 2014), then } \\
\text { it stands to reason } \\
\text { that low usage here } \\
\text { means that readers are } \\
\text { seen by the writer as } \\
\text { interpreters. }\end{array}$ & $\begin{array}{l}\text { Low usage shows that writer does } \\
\text { not value personal sentiment as } \\
\text { reliable tools to express identity; } \\
\text { low usage also shows that writer } \\
\text { attempting to be sophisticated } \\
\text { and values reason - leads to less } \\
\text { authoritative voice and indicates } \\
\text { lack of confidence (Rahimivand } \\
\text { \& Kuhi, 2014) }\end{array}$ \\
\hline $\begin{array}{l}\text { Engagement } \\
\text { markers }\end{array}$ & $\begin{array}{l}\text { Usage of inclusive } \\
\text { pronouns which indicates } \\
\text { dialogism with the } \\
\text { audience (Ramoroka, } \\
\text { 2017) shows } \\
\text { acknowledging importance } \\
\text { of persuasive engagement } \\
\text { in writing }\end{array}$ & $\begin{array}{l}\text { Usage of inclusive } \\
\text { pronouns indicates } \\
\text { dialogism with the } \\
\text { audience (Ramoroka, } \\
\text { 2017) - thus } \\
\text { implying the } \\
\text { performance of the } \\
\text { writer as, at the least, } \\
\text { a data guide as they } \\
\text { converse with the } \\
\text { imagined reader. }\end{array}$ & $\begin{array}{l}\text { Inclusive pronouns, } \\
\text { e.g., "we" (includes } \\
\text { readers) shows } \\
\text { awareness of the } \\
\text { need to engage the } \\
\text { reader in dialogue; } \\
\text { pulls the reader into } \\
\text { text (Ramoroka, } \\
\text { 2017). This lifts the } \\
\text { reader into the sphere } \\
\text { of being an interpreter, } \\
\text { but the possibility of } \\
\text { treating the reader } \\
\text { as a recipient is also } \\
\text { present. }\end{array}$ & $\begin{array}{l}\text { Inclusive language is said to be } \\
\text { indicative of dialogue with the } \\
\text { audience (e.g. Ramoroka's (2017) } \\
\text { discussion of inclusive pronouns). } \\
\text { This implies some form of } \\
\text { presence and voice that the } \\
\text { audience engages with, though } \\
\text { the confidence/visibility of that } \\
\text { voice will be moderated by other } \\
\text { metadiscourse markers such as } \\
\text { hedges and boosters. }\end{array}$ \\
\hline
\end{tabular}


Table 3. (Continued)

\begin{tabular}{|c|c|c|c|c|}
\hline & $\begin{array}{l}\text { Importance of } \\
\text { rhetoric (effective } \\
\text { persuasive writing) }\end{array}$ & Role of writers & Role of readers & $\begin{array}{l}\text { Writer identity (related: } \\
\text { expression of voice in writing) }\end{array}$ \\
\hline Self-mentions & $\begin{array}{l}\text { The frequency of } \\
\text { personal pronouns } \\
\text { can indicate the } \\
\text { writer's view on the } \\
\text { appropriateness of using } \\
\text { self-mentions (Truesdell, } \\
\text { 2014), which in turn } \\
\text { indicate the value } \\
\text { the writer places on } \\
\text { following the norms of } \\
\text { academic writing as they } \\
\text { perceive it. A high value } \\
\text { placed on following the } \\
\text { rules of rhetoric means } \\
\text { value placed on rhetoric. }\end{array}$ & $\begin{array}{l}\text { Exclusive } \\
\text { "we" (single } \\
\text { author, does not } \\
\text { include reader) can } \\
\text { show detachment } \\
\text { to text (Ramoroka, } \\
\text { 2017). This } \\
\text { detachment } \\
\text { precludes the } \\
\text { author as a } \\
\text { spokesperson due } \\
\text { to lack of explicit } \\
\text { commitment to } \\
\text { the text - the low } \\
\text { usage can mean } \\
\text { the writer acts as a } \\
\text { data guide or data } \\
\text { conveyer }\end{array}$ & $\begin{array}{l}\text { Inclusive pronouns, } \\
\text { e.g., "we" (includes } \\
\text { readers) shows } \\
\text { awareness of the } \\
\text { need to engage } \\
\text { the reader in } \\
\text { dialogue (Ramoroka, } \\
\text { 2017) - this means } \\
\text { the reader can be } \\
\text { seen as doing more } \\
\text { than just receiving } \\
\text { the data, though it } \\
\text { doesn't necessarily } \\
\text { mean that the reader } \\
\text { is only treated as an } \\
\text { interpreter. } \\
\text { If the writer uses } \\
\text { personal pronouns } \\
\text { in a way that } \\
\text { indicates them as a } \\
\text { data guide (e.g. "as } \\
\text { we will show"), } \\
\text { then that implies } \\
\text { seeing the reader } \\
\text { as an interpreter } \\
\text { of data (Truesdell, } \\
\text { 2014) }\end{array}$ & $\begin{array}{l}\text { This is the most explicit } \\
\text { indication of authorial identity } \\
\text { and helps create the rhetorical } \\
\text { self (Rahimivand \& Kuhi, } \\
\text { 2014) - high usage will mean a } \\
\text { confident authorial identity } \\
\text { Exclusive "we" (single } \\
\text { author, does not include } \\
\text { reader) can show detachment } \\
\text { to text (Ramoroka, 2017), } \\
\text { meaning minimal authorial } \\
\text { presence; inclusive "we" } \\
\text { indicates dialogue with } \\
\text { readers (Ramoroka, 2017), thus } \\
\text { some minimal form of authorial } \\
\text { presence } \\
\text { Low usage indicates lack } \\
\text { of confidence (Ramoroka, } \\
\text { 2017) and/or that } \\
\text { first-person pronouns are } \\
\text { inappropriate (Truesdell, 2014) }\end{array}$ \\
\hline
\end{tabular}

Table 4 and 5 for how relative high/low usage was calculated):

\begin{tabular}{lll}
\hline $\begin{array}{l}\text { Interactional } \\
\text { metadiscourse } \\
\text { category }\end{array}$ & $\begin{array}{l}\text { Frequency \& what } \\
\text { Table 3 says about the } \\
\text { frequency }\end{array}$ & $\begin{array}{l}\text { Placement } \\
\text { on a } \\
\text { continuum } \\
\text { for the } \\
\text { theme } \\
\text { (from } \\
\text { Table 2) }\end{array}$ \\
\hline Boosters & $\begin{array}{l}\text { High usage - writers } \\
\text { know the importance of } \\
\text { rhetoric }\end{array}$ & $\begin{array}{l}\text { Stage 3 } \\
\text { Attitude markers }\end{array}$ \\
$\begin{array}{l}\text { Second most common } \\
\text { in writing, but still low } \\
\text { usage - writers follow } \\
\text { rules of rhetoric in } \\
\text { academia }\end{array}$ & Stage 1-2 \\
Low - high number \\
wedges
\end{tabular}

\begin{tabular}{lll}
\hline Self-mentions & $\begin{array}{l}\text { High - writer knows } \\
\text { the importance of } \\
\text { persuasion and } \\
\text { negotiating claim } \\
\text { effectively } \\
(3+1.5+1+1.5+3) \div 5\end{array}$ & Stage 3 \\
& $\begin{array}{l}\text { categories } \\
\text { Overall placement } \\
\begin{array}{l}\text { on the theme } \\
\text { "Importance of } \\
\text { rhetoric" (average) }\end{array}\end{array}$ \\
\hline
\end{tabular}

\section{RESULTS}

\section{Steps 1 and 2: Quantitative Analysis of Usage of} Interactional Metadiscourse Markers

\section{Overall metadiscourse usage in the corpus}

Table 5 represents the coded observations of the overall use of interactional metadiscourse features by the ESL student-writers. From a table such as Table 5, the central tendency in the corpus of texts can be calculated (Lüdeling \& Kytö, 2009). The usage of interactional metadiscourse indicates construction of an authorial voice and presence in text through the expression of stance or engagement with the readers. The quantitative rates of occurrence of interactional metadiscourse have been normalised to per 1000 words. It is important to note that, as per Hyland's (2010) conceptualizations of metadiscourse in corpus linguistics, the frequency rates of metadiscourse, rather than conveying generalisations about the 
overall amount of metadiscourse in a text, are meant instead shed light on the different patterns of occurrence of metadiscourse in collections of text of varying sizes. This study takes this emphasis on patterns and extrapolates that rather than having an established standard rate/frequency that denotes high/low usage, the frequency rates of metadiscourse markers are instead meant to serve as comparatives.

The mean frequency/1000 for a particular metadiscourse marker is significant in how it is relative to the rates of other metadiscourse markers and the frequency rates of other linguistic features in a text. In other words, the frequency per 1000 words of boosters is significant because it shows that the student-writer uses boosters much more than, say, hedges which have a mean frequency of 10 per 1000 words. For this study, the relative frequency of the interactional metadiscourse markers was first established to calculate which interactional metadiscourse markers (from Table 1) the student-writers used most frequently to express their stance and/or engage the reader.

\section{Boosters}

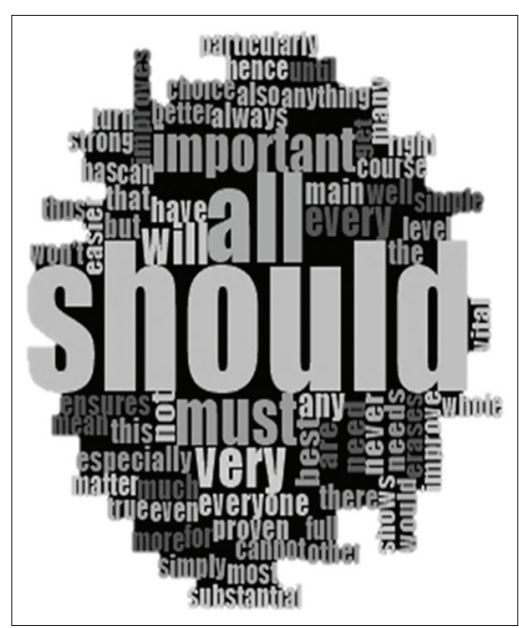

Boosters are phrases or sentences that emphasise the writer's commitment by implying certainty. The use of boosters means the presence of confidence in the propositional content (Hyland, 2010; Hyland \& Tse, 2004). Most of the corpus featured writing with strong claims and imperative language which served to emphasise propositions. The words "should" (total count: 60) and "all" (total count: 32) were featured particularly frequently in the corpus. Emphatic statements such as "Every organisation should..." frequently appeared throughout the corpora and are an indicator of the student-writers' stress on the strength of their claims; moreover, while the usage of "all" can indicate generalizations, all-encompassing statements such as "all rules and regulations apply to all ..." and "all organisations should ...", through their essential nature, have the effect of emphasis. The mean frequency per 1000 for boosters indicated that, on average, a booster was found every 32 words. This was far ahead of other interactional metadiscourse used in the corpus.

\section{Attitude Markers}

Attitude markers are those words/phrases which serve the function of expressing the writer's attitude toward the content.
These words/phrases can convey emotions such as surprise, obligation, agreement, importance, etc. (Hyland, 2010; Hyland $\&$ Tse, 2004). This study found that attitude markers were occasionally employed in a manner that worked in conjunction with other interactional markers such as boosters (that is, in the same phrase, such as "This shows that there is no proper rule...") and self-mentions (such as "From my point of view... is the main..."). For the most part, though, attitude markers frequently shared functioning with boosters - that is, one word/ phrase would be both a booster and an attitude marker, such as: "...to have a code of ethics is right."; " ... any society must have respect..."; "... ethical conduct is very much important...", All student-writers used "should" (with a tally of 57 in the corpus, occurring far more frequently than any other attitude marker) as both boosters and attitude markers. The mean frequency of attitude markers showed that, on average, an attitude marker appeared every 42 words in the corpus. This was only second behind the use of boosters and still far above the usage of other interactional metadiscourse markers.

\section{Hedges}

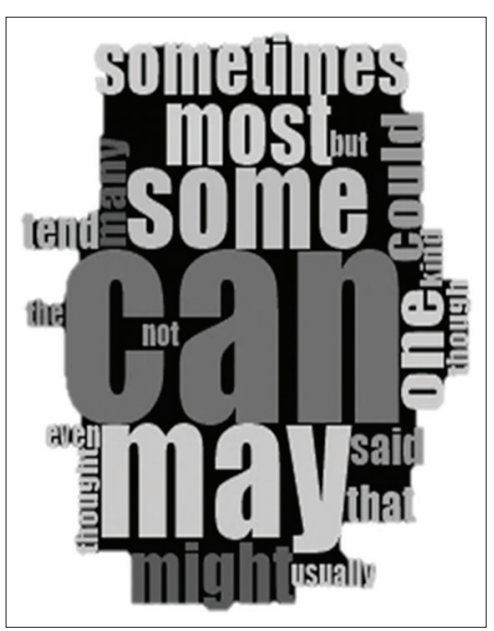

Hedges are used by writers to withhold their commitment to the argument - that is, it is a sign of the writer's reluctance to forcefully argue their proposition (Hyland, 2010; Hyland $\&$ Tse, 2004). Thus, the presence of hedges can imply the writer deliberately toning down the strength of their voice for reasons such as lacking confidence in their writing or content. However, hedges are also often used in academic discourse to comply with academic writing norms such as avoiding generalizations and acknowledging the reader as an evaluator of the proposition (Hyland, 2008) or establishing credibility by creating a passive tone in order to achieve the impartial tone that is often a requirement of academic writing (Hyland, 2008). Thus, the student-writers were possibly acknowledging some form of possibility when they wrote "...could be ..." while the usage of "...can is said that..." could be forms of following writing conventions by avoiding over-generalising despite having argued their points. However, in the corpus that this study analysed, at an average appearance of one hedge every 99 words, hedges featured relatively far fewer than the two most frequently occurring interactional metadiscourse markers. For example, the hedge "can" was the most frequent of the hedges at a total count of 
12 in the corpus, with "may" being the second most frequent hedge at a total of 10 in the corpus. This was far below the tallies of boosters and attitude markers and demonstrated the relatively low usage of hedges in the corpus.

\section{Engagement Markers}

Engagement markers are words and phrases which explicitly refer to or build a relationship with the audience/imagined reader(s) of the text (Hyland, 2010; Hyland \& Tse, 2004). The engagement markers in this study's corpus did this by directing the readers' attention to focus on something expressed in the text, such as "This shows that ..." and "It must be noted that...". Moreover, engagement markers can also serve their function by including readers as participants in the text through second person pronouns, imperatives, question forms and asides (Hyland \& Tse, 2004). This was more common in the corpus, with examples such as "... we have to follow ..." and "... so that people can trust you...", “... like we are different, our views, our personal views, our expectation...", and "... our beloved country...". The usage of engagement markers can mean a degree of awareness and appreciation of the importance of engaging the reader and building a relationship in rhetoric. However, in the corpus for this study, the relatively low frequency (see Tables 4 and 5) of attitude markers pointed towards a weak emphasis on reader engagement overall - the mean frequency of attitude markers indicated an average appearance every 140 words, which is quite far below the rates of other metadiscourse interactional markers.

\section{Self-mentions}

Self-mentions are a reflection of the degree of authorial presence regarding the occurrence of first-person pronouns and possessives (Hyland \& Tse, 2004). Self-mentions function as interactional metadiscourse through explicit reference to the author(s) of the text. While not the only indication of authorial voice, self-mentions are the most explicit indications of the author inserting themselves into the text, and high usage of this would indicate a high degree of authorial voice and confidence of expressing that voice. However, the corpus for this study had minimal self-mentions. Self-mentions were the lowest common interactional metadiscourse marker in the corpus, evidenced by the fact that only 4 of the 16 student-writers in the sample employed self-mentions in their writing, with rare examples such as “... once one grasps...”, "my", "we", "our" and "us". The low average frequency per 1000 words of self-mentions indicated a high reluctance to use this function to express authorial voice - self-mentions, on average, appeared every 315 words in the corpus.

\section{Relative usage of interactional metadiscourse functions in the corpus}

Keeping in mind that metadiscourse frequency statistics are meant to compare different patterns of occurrence of metadiscourse in corpora (Hyland, 2010), this study utilized the various average frequencies per 1000 words of the interactional metadiscourse markers investigated in this study and established relative high/low patterns of occurrence in the corpus analysed in this study. Using, as the high point, the frequency of the interactional metadiscourse with the most usage (that is, boosters, with an average frequency per 100 of 33), this study treated frequency rates below the quarter mark of the highest frequency as low usage, with those closest to the high point as high.

As such, using Table 4, the sample student-writer population were attributed relatively high or low levels of interactional metadiscourse usage in expressing their authorial voice.

The relative high/low usage of the various interactional metadiscourse categories were then cross-referenced (using Table 3) with themes from Leydens' continuum of rhetorical awareness (Table 2) to place the sample population on the continuum and then deduce implications about the student-writers' perceptions of their role as writers - particularly in terms of authorial identity and voice.

\section{Significance of the frequency of interactional metadiscourse}

Table 5 answers Research Question 1 of the article - that is, to what extent do first-year ESL student-writers at the Fiji National University use interactional metadiscourse to express their authorial voice in their academic writing. The word "extent" here may misplace the focus of the importance of the statistics - the true import of this finding is in recognition of how the statistical analysis of corpus can illustrate the importance of the discourse type on a frequency within a text (Jones \& Waller, 2015). In the case of this study, the discourse type is academic writing, and the average frequency of the interactional metadiscourse markers reveals significant aspects of how ESL student-writers express their authorial voice in writing:

i) firstly, the quantitative analysis indicated that students used interactional metadiscourse to express their authorial voice in their writing. The "extent" of interactional metadiscourse was identified by computing the frequencies of interactional metadiscourse usage in the student-writer texts. These frequencies were then compared to determine which metadiscourse markers were high/ low in usage. For instance, Table 5 illustrates that participants mostly used boosters and attitude markers to express their authorial voice and presence in their writing. By contrast, hedges were used very sparingly, while there was very little regarding direct engagement with the audience/imagined reader of the text. Significantly, self-mentions, which are the most explicit form of authorial voice, were very rare;

ii) secondly, the student-writers' self-perception of their role as writers and the role of the reader can also be worked out from the average frequency of the interactional metadiscourse markers. This was done in Step 3 of this study using Table 3, which crosses Leydens' continuum of rhetorical awareness with the interactional metadiscourse markers to show what the relative high/ low usage of metadiscourse means for the student-writers' perception of the writer and reader roles. 
Table 4. Scale of relative high/low frequency per 1000 words for metadiscourse categories

\begin{tabular}{lllll}
\hline $\mathbf{0}$ & $\mathbf{8}$ (quarter way) & $\mathbf{1 6}$ (midway point) & $\mathbf{2 4}$ (three quarters) & $\mathbf{3 3}$ \\
\hline low & low & high & high & \\
\hline
\end{tabular}

Table 5. Interactional metadiscourse usage levels in student essays

\begin{tabular}{lccccc}
\hline & Hedges & Boosters & Attitude markers & Engagement markers & Self-mentions \\
\hline Mean frequency/1000 & 10 & 32 & 24 & 7 & 3 \\
Relatively high or low & Low & High & High & Low & Low \\
\hline
\end{tabular}

\section{Step 3: Placing Respondents Along the Continuum of Rhetorical Awareness Using Relative Frequency of Interactional Metadiscourse Usage}

This study analysed ESL student-writers' performance of their role as authors and their interactions with their readers by placing the students along particular themes from Leydens' (2008) continuum of rhetorical awareness with the aim of gaining insight into the students' textually expressed perceptions of their role as writers and the role of their readers. The placement of the student-writers was done based on the relative frequency of interactional metadiscourse they used in their essays (using Table 3 with Table 5).

\section{The importance of rhetoric}

Boosters are an important feature in negotiating claims and effective argumentation in academic writing (Rahimivand \& Kuhi, 2014). The sample's high usage of boosters indicated an awareness of the importance of arguing claims persuasively in writing, and thus an appreciation of rhetoric (Stage 3). Attitude markers were the second most interactional metadiscourse used by the sample and indicated the valuing of expressing a personal opinion over rules of rhetoric (Rahimivand \& Kuhi, 2014). However, the attitude markers did not quite reach the high frequencies of boosters, showing some appreciation of following academic writing rules suggesting impartiality in tone while also indicating a clear emphasis on favouring strongly worded statements (Stage $1-2$ ). Results showed that hedges were quite low in number; a high number would have shown more emphasis on outright appreciation of the rules for limiting generalisation in persuasive writing at university. However, the low usage of hedges placed the participants at Stage 1 as the participants by large were not concerned with following rhetorical conventions of maintaining a balance between hedges and boosters. Likewise, the low use of engagement markers indicated an overall lack of value placed on outright engagement by using this category of metadiscourse; however, it must be noted that there were several, if relatively uncommon, instances of inclusive pronouns such as "we" which did indicate some level of interaction with the audience using engagement markers. While this low usage of engagement markers did not explicitly indicate a stage on the rhetorical awareness continuum, a relative lack of explicit engagement in persuasive writing did indicate a less-than-overt appreciation of persuasive engagement in rhetoric (Stage $1-2$ ). Finally, the sample employed self-mentions the least. This clear non-preference can be indicative of a lack of confidence; at the same time, this can also indicate an appreciation of rhetorical conventions regarding the appropriateness of personal pronouns and, thus, reflect the value the student-writers placed on following the rules of academic rhetoric (Stage 3). Overall, then, while the ESL student-writer sample displayed a mixture of acknowledgement and concern regarding rhetorical conventions, such as impartiality of tone for the importance of effective argumentation, they also tended to place more emphasis on the clear emphasis on boosting their arguments rather than balancing it with rhetorical techniques such as hedging. For this theme, then, the sample population could be placed on Stage 2 .

\section{Role of writers}

The observed high usage of boosters suggests the presence of strong authoritative persona for the student-writers in their texts (Rahimivand \& Kuhi, 2014). The consistent use of boosters, particularly "should" (most frequent at $21 \%$ of all boosters) showed that, overall, the sample acted more strongly as spokespersons rather than providers of their propositional content (Stage $3-4$ ). This placement on the continuum is backed up by attitude markers being the second highest interactional metadiscourse category used by the sample; a low number of attitude markers would have indicated a preference for toning down arguments (Rahimivand \& Kuhi, 2014). For the most part, though (110 cases out of a combined 371 between boosters and attitude markers served as both boosters and attitude markers), the relatively high attitude markers in the corpus served to act with the boosters to indicate that the writers were more than just conveying the content and were, in fact, acting as persuasive spokespersons for the ideas in the text (Stage 3). This idea of explicit commitment to the content was also supported by the low number of hedges. A high number of hedges would have shown deferring certainty (Truesdell, 2014) - a low number thus, again, implied the student-writers are acting as owners and spokespersons of content at Stage 3 or more of Leydens' continuum. However, the relatively low frequency of engagement markers in the corpus led to the impression of student-writers not operating at the highest level of engagement on the rhetorical awareness continuum. The lack of inclusivity did not push the sample population down to that of a mere data guide, though, as the inclusive "we" - which indicates dialogue (Ramoroka, 2017) - featured heavily in the albe- 
it relatively low instances of engagement markers. Thus, regarding engagement markers, the sample population acted as guides that did occasionally try to engage the audience while providing content (Stage $2-3$ ). Importantly, the sample population's performance as writers was also reflected in the relatively low frequency of self-mentions; the corpus did not feature the exclusive "we" which, while excluding the audience, would have - in cases of sole authorship such as the student essays - indicated detachment from the text (Ramoroka, 2017). Instead, the presence of inclusive pronouns such as "we" and "our", while scarce in the corpus, indicated that the student-writers were not detaching themselves from the text, suggesting that the sample was writing as impartial conveyers of data but did act at some level as spokespersons for their data (thus, Stage $2-3$ ). Overall, then, the sample population, while presenting content as arguments, also displayed personal investment in writing as spokespersons for their propositions (Stage 3).

\section{Role of readers}

The relatively high use of boosters seen in the data signals engagement with the readers (Rahimivand \& Kuhi, 2014), though it does not necessarily mean that the writer is seeing the readers as more than recipients because boosters can also act as attempts to influence the audience, indicating a perception of the readers as content recipients (Stage 2). The relatively high number of attitude markers were also indicative of the student-writers viewing readers as recipients (Stage 1) - a lower frequency of attitude markers would have indicated attempts to sound sophisticated (Rahimivand \& Kuhi, 2014) to persuade a critical academic audience. Similarly, a higher number of hedges would have given the more authority to readers (Rahimivand \& Kuhi, 2014) and more clearly treated readers as interpreters rather than recipients - this was not the case for this corpora. While there were some instances of hedges used to create a passive tone to cater for an academic audience (Truesdell, 2014), the relatively a low frequency of hedges in the corpus was indicative of the readers being viewed primarily as data recipients (thus, Stage 2). Furthermore, the low usage of engagement markers meant very little usage of the inclusive engagement markers that would have signposted an engagement with the reader and would have elevated reader to interpreter status. Thus, the sample population again seemed to be treating their readers as mostly data recipients (Stage 2). The same could be said of the relatively low usage of self-mentions in the corpus - while there were some instances of inclusive pronouns that had been used to engage and thus give importance to the reader, the usage of these was very low in the corpus, showing the overall inclination of the sample to view readers as content recipients mostly (thus, Stage 2). Overall, then, the student-writers appeared to consider readers as a mix between recipients and interpreters and tried to persuade the readers through strongly stated (boosted) content rather than pulling the readers in for equal engagement in dialogue (Stage 2).

\section{Writer identity (related to the presence of voice in the text)}

The high usage of boosters in the data reinforced the construction of authorial identity (Rahimivand \& Kuhi, 2014) - and thus the presence of an authorial voice - in the essays. This indicated confidence in their ability to affect the reader (Stage 4). Moreover, the relatively high usage of attitude markers in the corpus also helped to create a more authoritative voice and indicated the student-writers' confidence (Rahimivand \& Kuhi, 2014). It also meant that the sample population, overall, did place value on the expression of personal sentiment to express their authorial identity and advance their propositional content. Thus, the sample wrote as confident change agents (Stage 4). The confidence in expressing their personal stance was again displayed through the relatively low usage of hedges throughout the corpus. The low usage of hedges means that the student-writers were not overly concerned with keeping their identity 'safe' through hedging claims (Rahimivand \& Kuhi, 2014), and this, in turn, led to high authorial visibility in the text (Stage 4). However, the sample population displayed very little use of engagement markers to show authorial identity. The usage of engagement markers implies authorial presence as they are indicative of a dialogue with the readers (Ramoroka, 2017), meaning there is an authorial voice for the audience to have a dialogue with. However, for the usage of this particular interactional metadiscourse category, while there were some inclusive pronouns that implied dialogue with the readers, the sample population displayed the minimal use of explicit engagement (Stage 2). The same can be said of self-mentions, which are the most explicit way to express the rhetorical self. Self-mentions would have been the most direct way to express authorial identity and voice (Rahimivand \& Kuhi, 2014) - however, the especially low usage of self-mentions in the corpus indicated a lack of confidence in using this rhetorical strategy to express personal voice and stance. Nevertheless, the high crossing of self-mentions with engagement markers (of the total 27 self-mentions in the corpus, 24 also acted as engagement markers) did indicate that the sample used self-mentions, however rarely, in a bid to engage and persuade readers (Stage 2). Overall, then, the sample population appeared to be in Stage 4 in their expression of their writer identity in the text, displaying confidence in their ability to be change agents and writing with the goal to use the argument to persuade readers.

\section{Overall outside perspective}

Based on the analysis above, the ESL student-writer population were placed on particular themes of Leydens' continuum of rhetorical awareness using Table 3. The resulting placement is shown in Table 6, which shows the ESL student-writers' textually demonstrated (that is, the outside perspective (Leydens, 2008)) expression of their voice and identity as writers in academic writing, as well as their view of their readers.

\section{DISCUSSION AND CONCLUSION}

This study treated authorial voice as an expression of authorial identity in writing - in particular, the premise of 
Table 6. ESL student writer placement on rhetorical awareness continuum

\begin{tabular}{|c|c|c|c|c|}
\hline Characteristics & Stage 1 & Stage 2 & Stage 3 & Stage 4 \\
\hline Importance of rhetoric & $\begin{array}{l}\text { Denial of the relevance } \\
\text { or significance of } \\
\text { rhetoric }\end{array}$ & $\begin{array}{l}\text { On the cusp } \\
\text { between denial and } \\
\text { acknowledgement }\end{array}$ & $\begin{array}{l}\text { Overt } \\
\text { acknowledgement } \\
\text { of the importance of } \\
\text { rhetoric }\end{array}$ & $\begin{array}{l}\text { Like Stage } 3 \\
\text { but with greater } \\
\text { emphasis on } \\
\text { rhetoric's import }\end{array}$ \\
\hline Role of writers & Data conveyers & $\begin{array}{l}\text { Data conveyers and } \\
\text { data guides }\end{array}$ & $\begin{array}{l}\text { Data providers and } \\
\text { spokespersons }\end{array}$ & $\begin{array}{l}\text { Data } \\
\text { spokespersons and } \\
\text { providers }\end{array}$ \\
\hline Role of readers & Data recipients & $\begin{array}{l}\text { Data recipients and } \\
\text { interpreters }\end{array}$ & $\begin{array}{l}\text { Primarily data } \\
\text { interpreters }\end{array}$ & $\begin{array}{l}\text { Primarily data } \\
\text { interpreters }\end{array}$ \\
\hline $\begin{array}{l}\text { Writer identity (Note: } \\
\text { adapted to relate to the } \\
\text { importance of voice) }\end{array}$ & $\begin{array}{l}\text { Writer identity is } \\
\text { irrelevant; data } \\
\text { persuades, so a } \\
\text { spokesperson is } \\
\text { unnecessary }\end{array}$ & $\begin{array}{l}\text { Writer identity is } \\
\text { minimised, seen } \\
\text { as a novice, yet } \\
\text { sometimes writers } \\
\text { need to convince } \\
\text { readers }\end{array}$ & $\begin{array}{l}\ldots \text {.. context] } \\
\text { exigencies demand } \\
\text { a keen awareness } \\
\text { of audience and } \\
\text { persuasion }\end{array}$ & $\begin{array}{l}\text {...confident } \\
\text { change agents... } \\
\text { know how to } \\
\text { marshal data to } \\
\text { persuade readers }\end{array}$ \\
\hline
\end{tabular}

this study is that voice (and thus, authorial identity) in the act of writing is expressed through rhetorical strategies which include the expression of personal stance and engagement by the writer. To answer Research Question 1 , the study conceptualised the use of a particular rhetorical strategy - interactional metadiscourse - as the means by which student-writers can express their authorial voice and identity in their academic writing. The results of the quantitative analysis for interactional metadiscourse within the student-writer sample's writing determined the usage of interactional metadiscourse in the student-writers' writing, which indicated the extent to which this particular ESL student-writer sample expressed their personal voice in their writing. In understanding how the frequencies of interactional metadiscourse indicate the extent of usage by the student-writer sample, it is important to note that while the frequencies (per 1000 words) of each interactional metadiscourse function are one of the standard ways of indicating metadiscourse usage, these Tables are meant to be used relatively - that is, the frequencies of metadiscourse in texts are used to elaborate on different patterns of occurrence (Hyland, 2010). Thus, the extent of interactional metadiscourse usage is both revealed and significant through what the frequencies of metadiscourse occurrence illustrate about the relative usage of the various interactional metadiscourse functions. Discovering which interactional metadiscourse markers ESL student-writers use more frequently shed light on the rhetorical strategies ESL student-writers used to express their authorial self and engage with readers. Moreover, if a particular aspect of expressing the authorial voice is significantly under-used, then discovering the reasons for the relatively low usage of this metadiscourse function can inform teaching instruction.

The analysis of data suggests that participants had a strong tendency to use of boosters and attitude markers in revealing aspects of their personal voice and identity in their writing. The ESL student-writer sample for this study was very expressive and confident in revealing their authorial voice by strongly emphasising their propositional content. However, the extent to which authorial voice and identity were revealed through hedges, engagement markers and self-mentions were significantly less. This shows that the student-writers was more comfortable expressing their voice in the form of emphasis and indications of personal preference rather than expressing an authorial presence through limited certainty (hedges), explicitly engaging the audience (engagement markers) or mentioning themselves in their text (self-mentions). This discrepancy in the relative usage of the different interactional functions has implications for the student-writers' textually performed (outside) view of themselves as writers and the role of their readers.

The relatively high use of boosters does entail the construction of an authoritative authorial voice alongside being attempts to establish solidarity and engagement with readers (Rahimivand \& Kuhi, 2014) as the usage of boosters is essential for negotiation of claims and effective argumentation. Moreover, the significance of the high usage of boosters in the creation of an authoritative identity was evidenced by the inter-relation between the words and phrases which acted as both boosters and attitude markers - of the total 155 instances of attitude markers found in the corpus analysed for this study, 110 also acted as boosters. Usually, a high frequency of attitude markers would indicate a favouring of emotion or sensual perception (Rahimivand \& Kuhi, 2014) - however, the correlation between boosters and attitude markers is significant in that it indicated a preference for strongly effective engagement with the reader rather than an abandoning of reason over emotion. In other words, the ESL student-writers analysed in this study expressed their sentiment with the aim of using it to boost their persuasiveness and avoided expressing emotion which did not boost their proposition. Thus, it can be said that the ESL student-writers chose the use of strengthening expressions as a means of expressing their authorial voice, while at the same time attempting to maintain objectivity in their writing.

The perception of objectivity as a goal in academic writing is indicated, first, through the student-writers' use of hedges which, while lower than boosters and atti- 
tude markers, was still significantly higher than self-mentions and engagement markers - this showed that the student-writers leaned more towards limiting their certainty and protecting their identity than outright engagement with the readers or explicit self-references in the text. The use of hedges leads to a passive voice that is geared towards establishing a passive tone in academic texts; this use of hedges for a passive, impartial tone is a common feature of ESL writing (Truesdell, 2014). Combined with the relatively very low use of self-mentions in the corpus, it can be deduced that even though the ESL student-writer population analysed in this study indicated high authorial visibility due to their more frequent use of boosters and attitude marker, the student-writers also generally avoided the most explicit form of authorial presence (self-mentions) and attempted to follow academic norms of impartiality in tone through hedging their claims. This is indicative of the importance and consequence of received writing instruction, particularly for ESL students that have low self-efficacy with English writing. Thus, the extent to which the ESL student-writers expressed their authorial voice may be influenced by the writing instruction they received.

Overall, the ESL student-writer sample for this study showed that they do utilise interactional metadiscourse albeit some functions more than others - to express their authorial voice and identity in their writing. For example, considering the investigations that this study emulated, the total frequency of interactional metadiscourse usage for this study is much higher than the frequency total of Ramoroka's (2017) examination of interactional metadiscourse in undergraduate ESL writing. Moreover, the frequency of interactional metadiscourse and expression of voice in writing found in this study is also quite higher than Rahimivand and Kuhi's (2014) investigation of the use of interactional metadiscourse (excluding engagement markers) by ESL writers in research articles; Rahimivand and Kuhi's (2014) total of 21.5 per 1000 prompted them to conclude that their student-writer sample was attentive to setting up their identities through metadiscourse usage - by extension, then, the ESL student-writer analysed here, with an overall interactional metadiscourse usage of 69 per 1000 for the same metadiscourse functions, also evidently utilized interactional metadiscourse to express their voice and identity in writing.

Determining the extent to which the student-writers expressed their authorial voice indicated how the ESL student-writers textually performed their authorial identity and their engagement with their imagined reader. Table 6 demonstrates the sample's textually determined rhetorical awareness. To sum up, the extent to which the ESL student-writers expressed their voice in their writing showed that, regarding their outside perspective on the role of writers, the student-writer sample tended to write as providers of and spokespersons for (Stage 3) their propositional content. The student-writers' texts managed to have content which was organised into the familiar outline of the Introduction-Body-Conclusion format of an expository essay, with interactive linking words such as "therefore" and "in conclusion" to guide the reader along the content and present prop- ositions in a manner recognisable to an academic audience. Thus, the student-writers presented the characteristics of writing as basic conveyers and guides for their content. This conforming to disciplinary methods clearly shows the influence of the discourse community on the student-writers modes of expression.

Moreover, the usage of interactional metadiscourse indicated that the student-writers were also acting as spokespersons for their propositional content. The high use of boosters and attitude markers created an authoritative persona which emphasised their arguments and actively attempted to persuade the reader. Notably, however, the student-writer sample did not write as content-spokespersons primarily - the presence, though low, of hedges which act to defer certainty and produce a passive tone in text, meant that the student-writers did not overtly and consistently promote their personal voice. Moreover, the relatively low usage of explicit engagement markers and self-mentions - that indicated the absence of a more committed and explicit authorial presence's dialogue with readers - meant that the student-writers were not operating primarily as spokespersons for their argument yet did see the need to boost their personal propositions for rhetorical effect. Thus, the overall outside perspective of the role of the writer, for the ESL student-writers of this study, is at Stage 3 - the student-writers write in a way that indicates they see themselves as providers of their content and also feel the need to boost their personal voice - to an extent - in order to persuade their readers.

Participants in this study wrote in a way that indicated that they viewed their readers as falling in a range between recipients and interpreters of content (Stage 2). The extensive use of boosters in their writing built solidarity and engagement (Rahimivand \& Kuhi, 2014) with the audience, thus indicating an apparent attempt to engage with the imagined reader of their text. The high extent to which boosters were used by the student-writers to express their personal voice in writing also indicated an outside perspective of the readers as impressionable recipients - this was further backed up by the high use of attitude markers which showed that the student-writers were confident in expressing their personal stance to the readers. Notably, the high inter-relation between boosters and attitudinal markers also indicated that the student-writers treated the readers as an audience who are recipients of data and, as such, can be persuaded through rhetorical strategies such as emphasised propositional content. However, the presence of hedges, while relatively low, did indicate some recognition of the critical power of the reader - similarly, the presence, albeit low, of engagement markers and inclusive self-mentions meant that the student-writers did not see the readers as merely recipients (Stage 2).

The significance of the extent of metadiscourse usage in this study illustrates the importance of the type of writing the writer is doing, and how the writing influences the frequencies of linguistic patterns found in the writer's text (Jones \& Waller, 2015). It also reveals the extent to which the student-writers revealed their authorial identity and voice in academic writing. As the frequencies of metadiscourse usage are meant to shed light on the relative use of 
the different metadiscourse functions, the student-writer sample in this study were more comfortable using boosters and attitude markers, but - perhaps due to adhering to the passivity required in academic writing - were hesitant or uncomfortable in their usage of engagement markers and self-mentions to express their authorial voice; this can inform the writing instruction for academic writing. While there are no benchmarks for the frequencies of metadiscourse in good academic writing, research has shown that ESL undergraduate writing is affected positively by the inclusion of metadiscourse - better-graded essays are found to have more and a wider variety of metadiscourse than poorly graded ones (Intaraprawat \& Steffensen, 1995). Indeed, explicit metadiscourse instruction has been shown to yield essays which receive higher grades for university-level ESL student-writers (Cheng \& Steffensen, 1996).

Another pedagogy-related implication of the deduced frequencies of interactional metadiscourse usage can be worked out in comparison with the other investigations of metadiscourse and authorial voice. For example, as discussed above, the total frequency of interactional metadiscourse usage for this study is far surpassed than the frequency total of interactional metadiscourse in Ramoroka's (2017) investigation of undergraduate ESL writing. It is to be noted that the researcher's subjectivity regarding identifying possible metadiscourse functions, as well as cultural, linguistic and other contextual differences amongst the sample populations involved in other investigations of authorial voice may have played a part in the differences in resultant interactional metadiscourse frequencies. Nevertheless, a further possible reason for the higher metadiscourse count in this study could be that studies such as Ramoroka's (2017) utilised actual academic assessments, while this study, to gauge the self-reflective writing practices of the ESL, attempted to exclude the inclusion of other voices by the student-writers. The consequence of not having to include other voices through referencing, along with the relieving pressure of the text not counting as assessment, may have prompted writing with more authorial expression through freedom and lack of choice. However, this then leads to an interesting point - if the ESL student-writer does feel freer to include more of their authorial presence in the absence of other voices, then writing instruction can take note of this to help budding student-writers develop their authorial presence in writing.

In conclusion, this study explored the extent to which ESL first-year students at the Fiji National University used interactional metadiscourse to express their authorial identity in their academic writing and extended the investigation to the student-writers' performance and perceptions of their role as writers and the role of their readers. The study found that the student-writers did express their identity in writing but mostly through using boosters and attitudinal markers - these metadiscourse functions serve to boost propositional content and express personal opinions. Further analysis of the student-writers' texts, using Leydens' (2008) continuum of rhetorical awareness, showed that the student-writers were writing as confident change agents, displaying an authorial role as providers of content who occasionally also acted as committed spokespersons for their ideas - however, this confidence was moderated by the influence of the academic discourse community's academic writing norms, such as the rules for achieving passivity through avoiding explicit self-mention or expression of overt personal sentiment. While the study was limited in its scope and number of participants, some clear pedagogical implications for empowering ESL students-writers can be drawn:

- The study recommends more explicit instruction of the full range of rhetorical strategies available for ESL student-writers to include their personal voice in academic writing;

- The study also recommends the precise rescinding of the stigma associated with particular categories of self-expression in academic writing - in particular, self-references and inclusive engagement markers should be fostered more in academic writing to encourage ESL writers to include more of their personality in their academic writing;

- The study recommends further investigation into the matter of textual performance of ESL student-writer identity and suggests comparisons with internal perceptions to gain new insight into the development of the ESL authorial voice.

\section{REFERENCES}

Abdi, R. (2002). Interpersonal metadiscourse: An indicator of interaction and identity. Discourse Studies, 4(2), 139-145. doi: https://doi.org/10.1177/14614456020040 020101

Abdi, R. (2009). Projecting cultural identity through metadiscourse marking: A comparison of Persian and English research articles. Journal of English Language Teaching and Learning, 1(212), 1-15.

Alward, A. S., Mooi, C. C., \& Bidin, S. J. B. (2012). Hedges and boosters in the Yemeni EFL undergraduates' persuasive essay: An empirical study. The Internet Journal of Language, Culture and Society (34), 1-12.

Cheng, X., \& Steffensen, M. S. (1996). Metadiscourse: A technique for improving student writing. Research in the Teaching of English, 30(2), 149-181.

Elbow, P. (1988). Writing with power: Techniques for mastering the writing process $\left(2^{\text {nd }}\right.$ ed.). New York, NY: Oxford University Press.

Elton, L. (2010). Academic writing and tacit knowledge. Teaching in Higher Education, 15(2), 151-160. doi: https://doi.org/10.1080/13562511003619979

Gemmell, R. (2008). Encouraging student voice in academic writing. The English Journal, 98(2), 64-68.

Halliday, M. A. K. (1978). Language as social semiotics. London, England: Edward Arnold.

Halliday, M. A. K. (1985). An Introduction to functional grammar. London, England: Edward Arnold.

Harwood, N. (2005). 'We do not seem to have a theory... the theory I present here attempts to fill this gap': Inclusive 
and exclusive pronouns in academic writing. Applied Linguistics, 26(3), 343-375. doi: https://doi.org/10.1093/ applin/ami012

Hickey, D. J. (1993). Developing a written voice. Mountain View, CA: Mayfield Publishing Company.

Hyland, K. (2002a). Authority and invisibility: Authorial identity in academic writing. Journal of Pragmatics, 34, 1091-1112. doi: https://doi.org/10.1016/S03782166(02)00035-8

Hyland, K. (2002b). Options of identity in academic writing. ELT Journal, 56(4), 351-358.

Hyland, K. (2004). Disciplinary discourses: social interactions in academic writing. Ann Arbor, MI: University of Michigan.

Hyland, K. (2008). Persuasion, interaction and the construction of knowledge: Representing self and others in research writing. International Journal of English Studies, 8(2), 1-23. doi: https://doi.org/10.6018/ ijes.8.2.49151

Hyland, K. (2010). Metadiscourse: Mapping Interactions in academic writing. Nordic Journal of English Studies, 9(2), 125 - 143.

Hyland, K., \& Tse, P. (2004). Metadiscourse in academic writing: A reappraisal. Applied Linguistics, 25(2), 156177. doi: https://doi.org/10.1093/applin/25.2.156

Intaraprawat, P., \& Steffensen, M. S. (1995). The use of metadiscourse in good and poor ESL essays. Journal of Second Language Writing, 4(3), 253-272. doi: http://dx. doi.org/10.1016/1060-3743(95)90012-8

Ivanič, R. (1998). Writing and identity: The discoursal construction of identity in academic writing. Amsterdam, Netherlands: John Benjamins.

Jarkas, N., \& Fakhreddine, J. (2017). The dance of voices: A study on academic writing at AUB. In L. R. Arnold, A. Nebel, \& L. Ronesi (Eds.), Emerging writing research from the Middle East-North African region (pp. 241-263). Fort Collins, CO: The WAC Clearinghouse and University Press of Colorado.

Jones, C., \& Waller, D. (2015). Corpus linguistics for grammar: A guide for research. London, England: Routledge.

Leydens, J. A. (2008). Novice and insider perspectives on academic and workplace writing: Toward a continuum of rhetorical awareness. IEEE Transactions on Professional Communication, 51(3), 242-263. doi: https://doi. org/10.1109/TPC.2008.2001249

Lillis, T. (1997). New voices in academia? The regulative nature of academic writing conventions. Language and Education, 11(3), 182-199. doi: https://doi. org/10.1080/09500789708666727

Lin, S. M. (2015). A study of ELL students' writing difficulties: A call for culturally, linguistically, and psychologically responsive teaching. College Student Journal, 49 (2), 14 pages. Retrieved from https://www.questia. com/library/journal/1G1-419267902/a-study-of-ell-students-writing-difficulties-a-call

Lüdeling, A., \& Kytö, M. (Eds.). (2009). Corpus linguistics: An international handbook (Vol. 2). Berlin, Germany: Walter de Gruyter GmbH \& Co.
Maharaj, M. (2014, November 13). English 'inadequacies'. The Fiji Times Online. Retrieved from http://www.fijitimes.com/story.aspx?id=286002

McEnery, T., \& Hardie, A. (2012). Statistics in corpus linguistics. Support website for corpus linguistics: Meth$o d$, theory and practice. Retrieved from https://corpora. lancs.ac.uk/clmtp/2-stat.php

Nelson, M. W. (1991). At the point of need: Teaching basic and ESL writers. Portsmouth, NH: Heinemann.

Nicholls, L. (2014). What is the socio-linguistic context for teaching English writing to senior high school students in Fiji? (Master of Philosophy), Massey University, Palmerston North. Retrieved from http://hdl.handle. net/10179/5748

Pittam, G., Elander, J., Lusher, J., Fox, P., \& Payne, N. (2009). Student beliefs and attitudes about authorial identity in academic writing. Studies in Higher Education, 34(2), 153-170. doi: https://doi. org/10.1080/03075070802528270

Prior, P. (2001). Voices in text, mind, and society: Sociohistoric accounts of discourse acquisition and use. Journal of Second Language Learning, 10(1$2)$ 55-81. doi: https://doi.org/10.1016/S10603743(00)00037-0

Rahimivand, M., \& Kuhi, D. (2014). An exploration of the discoursal construction of identity in academic writing. Procedia - Social and Behavioral Sciences, 98, 1492-1501. doi: https://doi.org/10.1016/j.sbspro.2014.03.570

Ramoroka, B. T. (2017). The use of interactional metadiscourse features to present a textual voice: A case study of undergraduate writing in two departments at the University of Botswana. Reading \& Writing, 8(1), 11 pages. doi: https://doi.org/10.4102/rw.v8i1.128

Riazi, A. M. (2016). The Routledge encyclopedia of research methods in applied linguistics: quantitative, qualitative, and mixed-methods research. New York, NY: Routledge.

Riyanti, D. (2015). An exploration of voice in second language writing. The Nebraska Educator: A Student-led Journal, Paper 28.

Salek, M. (2014). A diagram of interactive and interactional markers in different parts of English research articles Journal of Language Sciences \& Linguistics, 2(3), 55-66.

Sperling, M., Appleman, D., Gilyard, K., \& Freedman, S. (2011). Voice in the Context of Literacy Studies. Reading Research Quarterly, 46(1), 70-84. doi: https://doi. org/10.1598/rrq.46.1.4

Swales, J. M. (1990). Genre analysis: English in academic and research settings. Ann Arbor, MI: Cambridge University Press.

Thompson, G. (2001). Interaction in academic writing: learning to argue with the reader. Applied Linguistics, 22(1), 58-78. doi: https://doi.org/10.1093/applin/22.1.58

Thompson, G., \& Thetela, P. (1995). The sound of one hand clapping: The management of interaction in written dis- 
course. TEXT - Interdisciplinary Journal for the Study of Discourse, 15(1), 103-127. doi: https://doi.org/10.1515/ text.1.1995.15.1.103

Truesdell, D. (2014). Constructing identity in academic writing: A case study on rhetorical awareness in engineering discourse. Stylus, 6(1). Retrieved from Stylus: A journal of first-year writing website: http://writingandrhetoric. cah.ucf.edu/stylus/files/6_1/Stylus_6_1_Truesdell.pdf Zhao, C. G. (2012). Measuring authorial voice strength in L2 argumentative writing: The development and validation of an analytic rubric. Language Testing, 30(2), 201-230. doi: https://doi.org/10.1177/0265532212456965 